\title{
The leadership challenges of Paul's collection for the saints in Jerusalem: Part II: Overcoming the obstacles on the side of the recipients and of Paul
}

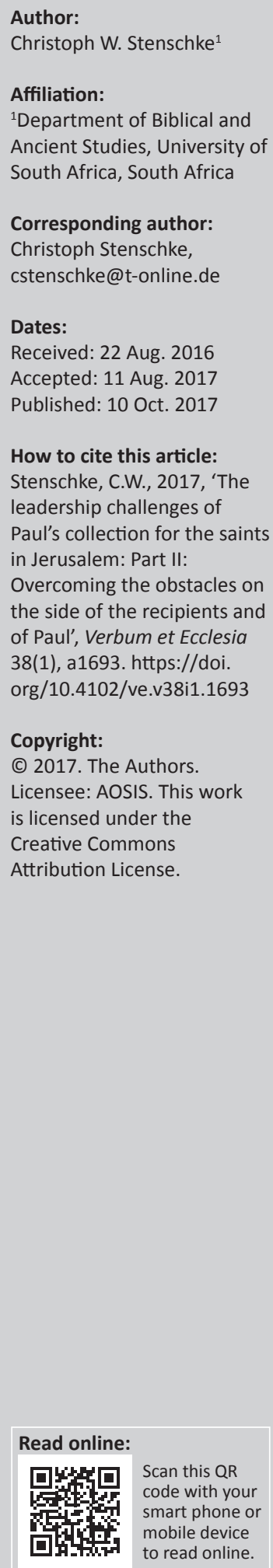

Paul tried to convince the predominantly Gentile Christian churches to contribute to a collection for the impoverished Jewish Christians of Jerusalem. While Paul is best known as a theologian, missionary and pastor, his collection project also shows his skills as an early Christian leader. Part II of this article describes what obstacles Paul had to overcome on the side of the Jewish Christian recipients of the collection, how he did so and how he proceeded in preparing and organising the actual collection, the transport and presentation of the funds in Jerusalem. It also discusses what obstacles were involved for Paul personally in this project and how he dealt with them. In closing, the article relates the portrait of Paul the leader as it emerges in this enterprise to modern leadership theory. Paul's leadership evinces elements of servant leadership, authentic leadership and adaptive leadership.

Intradisciplinary and/or interdisciplinary implications: The article indicates to what extent early Christianity was affected by and had to interact with the political situation of its day. It also shows the complexities of Paul's life and ministry and his relations to the church in Jerusalem. It also provides an example of how Paul can be related to current leadership theory and suggests that awareness of this discourse sheds fresh light on Paul.

\section{Introduction}

In the first part of this essay, 'The leadership challenges of Paul's collection for the saints in Jerusalem: Part I: Overcoming the obstacles on the side of the Gentile Christian donors' (Stenschke 2015), we first briefly surveyed the origin and development of Paul's collection for the saints of Jerusalem (The origin and development of Paul's collection). Then we examined what was involved on the side of the Gentile Christian donors (with a focus on Corinth - following the available sources regarding obstacles on the side of the Gentile Christian donors). We described five obstacles that had to be overcome in order to get the donors involved (ancient local patronage and local honour, ancient anti-Judaism, Paul's quarrels with the Corinthians and the presence of opponents, Paul's financial policy in Corinth and other previous financial engagements of the Corinthians) and how Paul addressed these obstacles and tried to overcome them in 1 Corinthians 16 and 2 Corinthians 8-9 (Paul's responses to these obstacles). After this exegetical survey, we summarised at the end of this section how Paul addressed these obstacles and advanced this project which involved so many pitfalls. In the final section (Conclusion) we analysed the exegetical data in view of the recent discussion about leadership theory and practice (The portrait of Paul the Leader in overcoming the obstacles on the side of the Gentile Christian donors). The aim was to utilise the 'Paul and the gift' issue as a basis for understanding Paul's leadership style. Not surprising, it proves to be a combination of different approaches. While other elements according to modern notions of leadership are also discernible, in overcoming the obstacles on the side of the Gentile Christian donors, Paul's leadership predominantly resembles what has been described as charismatic or transformational leadership (Stenschke 2015:11-13; for a survey, see Northouse 2016:161-193).

Part II of this study follows the same pattern and focuses on the leadership challenges involved in overcoming the obstacles on the side of the Jewish Christian recipients and on the side of Paul himself. We first examine the obstacles on the side of the Jewish Christians in Jerusalem (Obstacles on the side of the recipients of the collection and Paul's answer). ${ }^{1}$ How did or would Paul address them?

\footnotetext{
1.Like in Part 1 , with the label 'Gentile Christians' we refer to believers in Jesus from a non-Jewish background. 'Jewish Christians' are believers from a Jewish background, that is, Jewish believers in Jesus. The term 'Hellenistic Jews' is not helpful, as all Jews in the first century $A D$ were to some extent Hellenised. Where necessary, we distinguish between Jews in Judea and in the Jewish Diaspora. For a survey of the knotty issues involved in the definition and description of various social identities involved in such modern scholarly classifications, see Skarsaune and Hvalvik (2007:3-52).
} 
We also ask what obstacles Paul himself had to overcome in his collection project and how he went about it (Obstacles on the side of Paul himself and his response). A final section (The portrait of Paul the leader in overcoming the obstacles on the side of the Jewish Christian recipients and on his own side: Summary and analysis) again analyses and describes the portrait that emerges of Paul in view of recent discussion about leadership theory and practice. It is also the aim of this essay to analyse the 'Paul and the gift' issue as a basis to better understand Paul's leadership style. With our focus on the leadership challenges surrounding Paul's collection for the saints in Jerusalem, we draw on texts and issues which so far have hardly been considered in the discussion of leadership issues with regard to Paul.

While the aspects of charismatic or transformational leadership identified in Part I continue to emerge, in overcoming these obstacles Paul's leadership is characterised by elements of what has been described as servant leadership in past decades and by other trends which have emerged in leadership studies in the early 21st century such as authentic leadership and adaptive leadership (for a survey, see Northouse 2016:4f.; for detailed descriptions, see Northouse 2016:195-223, 257-294). Like Part I, this essay is situated at the intersection of historical socio-rhetorical inquiry and leadership theory. ${ }^{2}$

\section{Obstacles on the side of the recipients of the collection and Paul's answer}

In Romans 15, Paul first writes in some detail about the donors of the collection and of their motivation (15:25-28). ${ }^{3}$ The recipients only appear as the object of the activity of Paul's communities:

I am going to Jerusalem bringing aid to the saints. For Macedonia and Achaia have been pleased to make some contribution for the poor among the saints in Jerusalem. For they were pleased to do it, and indeed owe it to them. For if the Gentiles have come to share in their spiritual blessings, they ought also to be of service to them in material blessings. When therefore I have completed this and have delivered to them what has been collected, ...4

Only in Romans 15:31 does Paul speak about the recipients of the collection and provide an interesting detail. He voices his doubts as to its eventual acceptance: 'and that my ministry to Jerusalem may be acceptable to the saints'. Up to that point, Paul either presents himself as fully confident or appears to have indeed been confident as to the benefits on both sides and the welcome which the collection and its delegates would receive in Jerusalem (see 2 Cor 9:14: 'while they long and pray for you ...', which is in its own way a recognition of the donors). What obstacles to receiving the collection were

2.Because of the constraints of space and the latter focus on leadership theorising, cannot offer a detailed theoretical discussion of this approach. The second part of this essay is more discernably theory-informed than its exegetical first part.

3.Only 1 Corinthians $16: 3$ indicates that the gift is to be brought to Jerusalem 1 Corinthians $16: 1$ simply speaks of 'the collection for the saints'. 2 Corinthians $8 \mathrm{f}$ does not mention at all, where 'the saints' are located.

4.Unless otherwise indicated, the translations of biblical texts follow the English Standard Version (ESV 2001). there on the side of the Jewish Christians of Jerusalem? Unfortunately, we do not have the letter which Paul announced in 1 Corinthians 16:4 (if this letter of explanation and recommendation was ever written by him; after all, Paul later decided to travel with the delegates), nor do we have other direct contemporary Christian sources regarding the situation in Jerusalem. As far as we know, Paul did not prepare for his impending visit to Jerusalem with a letter as was the case with the Roman Christians to whom he intended to travel after the collection had been delivered (see Rm 1:10$15 ; 15: 22-32)$.

At least as far as Paul was concerned, for the Jewish Christians of Jerusalem to accept the donation and with it also its donors meant the recognition of at least some Gentile Christians as part of the people of God. ${ }^{5}$ Paul leaves no doubt that money and donors are inextricably linked and that the donors cannot be divided up along a Jew-Gentile dividing line; although, admittedly, this link may not have been the case for (all) the donors and for (all) the recipients. But he would come himself, explain in detail and insist that this link is not negotiable. Many or perhaps most of Paul's Gentile Christians had not become full proselytes (for a description and the implications, see Burns 2010) and apparently had no intention to do so. It is not clear to what extent they actually lived according to the regulations of the so-called apostolic council of Acts $15 .{ }^{6}$ In view of the Jewish prejudices against Gentiles (for surveys, see Gilbert 2010 and Palmer 2015; for a detailed study, see Donaldson 2007), some of them based on the Scriptures of Israel, the acceptance of these Gentile Christians being and remaining Gentiles was a challenge and obstacle to accepting the collection. But more than that was involved.

Paul carefully planned the transport and actual delivery of the collection: not only he, but also a larger group of delegates and representatives of the Gentile Christian churches of various regions (mentioned in 1 Cor 16:3f.; 2 Cor 8f.) would come along and be present in Jerusalem. The delegation probably consisted of the people listed in Acts 20:4:

Paul was accompanied by Sopater, son of Pyrrhus from Beroea, by Aristarchus and Secundus from Thessalonica, by Gaius from Derbe, and Timothy, as well as by Tychicus and Trophimus from Asia.

Probably others were also involved (it is unclear how this list relates to the people mentioned by Paul himself).

By accepting the collection the Christians of Jerusalem ${ }^{7}$ they would not only express their bond with the Jewish Diaspora

5.For a discussion of the identity of the donors, see note 7 .

6.Acts 15:20. The regulations are repeated in Acts 21:25 in the context of Paul's visit to Jerusalem, although the collection is not mentioned at all. Paul never refers to the decision of the council in Jerusalem in his letters. There are various explanation for this fact. The acceptance of full proselytes would not have been problematic.

7.Paul simply refers to the 'saints in Jerusalem' ( $\mathrm{Rm} 15: 26)$ and does not indicate whether there are several and different groups in the city or differentiate between them. According to the portrayal of Acts 21 the community or communities there them. According to the portrayal of Acts 21, the community or communities there consists of a large suspicious of Paul (21:20-21). The leadership stands behind Paul and his Gentile mission. On hearing Paul's report of the things that God had done among the Gentiles through his ministry, they glorify God $(21: 19-20)$. While both groups, this larger group and the leadership, would not have had any reservations regarding 
and Jewish Christian communities outside of Jerusalem (there is no evidence of this ever being problematic). They would also accept the (predominantly?) Gentile Christian donors either with their drastically reduced observance of the law (according to the compromise of Acts 15) or no observance of the law. Acceptance would also include Paul and his controversial gospel and ministry.

This assessment depends on the question of the sources of the contributions which Paul collected for this project. While Paul left no doubt that all Corinthian Christians must contribute ('each of you is to put something aside'; 1 Cor 16:2), we do not know what actually happened (the difficulties regarding the donors have been discussed in detail in Part I). Of the money, which Paul obtained, did the contributions mainly come from Gentile Christians or from Jewish Christians? Did Paul himself know of the exact composition? Was it of concern to him? If he received them from both groups, would Jewish believers in Jerusalem know of it and see the difference? In the few references to the collection, Paul is silent about the matter. The fact that the delegation which was to deliver the collection included Gentile Christians suggests that Paul would hardly be silent about its origin. The complexity of the matter may have been one of the reasons why Paul decided to go in person to Jerusalem to deliver the collection and explain its origin and purpose. This question is linked to the difficult issue of the make-up of Paul's communities: what was the ratio between Jewish Christians and Gentile Christians? Did all communities contain members from both groups? It is impossible to determine to what extent members from both groups contributed to the collection in the various communities. According to the report about the famine relief collection in Acts 11:27-30, all Christians contributed from a community which consisted of Jewish and Gentile Christians. One might also inquire whether the Jewish believers in the areas mentioned in the context of the collection still contributed to the annual Jewish temple-tax or brought their tithes in whatever form there (see Levine 2010:1289-1290). Did some of them see such payments as their sufficient contribution to Jerusalem and thus refrain from contributing to Paul's collection?

In Paul's understanding and foreseeable insistence on this point, by accepting gift and givers, the Jewish Christians would establish and express their bond with the Gentile Christians among the donors as legitimate partakers in God's salvation for Israel. ${ }^{8}$ This step would require a revision of their estimate of Gentiles and the courage to read some of their Scriptures in a new way or to jettison some of its regulations. In their understanding, this would probably also include a reassessment and/or relegation of Jewish privileges on their side. ${ }^{9}$

\section{(footnote 7 continues...)}

gifts from Jews in Judea or the Diaspora, the larger group presumably had its qualms about non-Jewish donors and Paul's idea of fully accepting them as Gentiles into the people of God. There is evidence that gifts from some Gentiles were accepted by some Jews in Judea. This would have been the case under different political circumstances (i.e. before the turn of attitude from the mid-fourties of the first century AD onward, see below) and/or when no strings were attached regarding the full acceptance of the donors or regarding a modification of Jewish identity.

8.Obviously this would not apply to the Jewish Christians among the donors.

9.See the objections voiced in Acts 11:1-18 and the demands that were made by some Christians of Jerusalem on the Gentile Christians of Antioch in Acts 15:1-29: 'Unless you are circumcised according to the custom of Moses, you cannot be saved'.
All this would take place in Jerusalem, the very centre of Judaism, and would, most likely, not remain an innerChristian matter but become known to a wider critical public, both during Paul's stay in the city and after his departure. ${ }^{10}$ Jews who would relativise their own Jewish privileges and identity in this way (or be perceived by others as doing so) and accept Gentiles as Gentiles into the people of God would face criticism and resistance from at least a certain number of their fellow Jews ${ }^{11}$ in the increasingly politically tense climate of the two decades leading up to the first Jewish war (66 AD$73 \mathrm{AD}$ ). This was the time of increasing zealotism and of the sicarii, a group of assassins who with their daggers (Latin sicarius) secretly killed those whom they suspected of collaborating with the Gentile Roman occupants of Israel (for a survey, see Schürer, Vermes \& Millar 1973:455-470; the sicarii were part of the larger phenomenon of Jewish resistance, see McLaren 2010).

This historical context of the collection and its delivery in Jerusalem is worth considering as it posed a major challenge for Paul. We summarise its excellent description by Bo Reicke who relates the larger contexts to the developments within early Christianity (for a more recent survey, see Seeman \& Marshak [2010]; for a detailed study, see Goodblatt [2006], Goodman [1987] and Price [1992]). Reservations against Gentiles were already strong in the forties of the first century. Reicke (1968:201) argues that the persecution of James and Peter through Herod Agrippa I in about 42 AD (Ac 12) was because of feelings of prosperity and expansion among the Jews. This led to the desire to repress all elements that seemed alien to Judaism. The removal of James and Peter was intended to cripple a movement that had at least some associations with Gentiles (e.g. in Antioch). ${ }^{12}$

When Judea came under direct Roman control after the death of Herod Agrippa in $44 \mathrm{AD}$, there was a strong and prolonged Jewish response:

The surprisingly violent Jewish reaction was more likely due to the political situation. The glory of Herod's kingdom, restored according to strict religious principles under Agrippa I, had to suddenly vanish. From the very outset, therefore, the Jews detested their new guardians. Added to this anger must be the turbulent struggle between Greek and Jewish culture. About $50 \mathrm{AD}$, Claudius had the Jews banished from Rome. In $52 \mathrm{AD}$,

10.Later Trophimus was recognised as a Gentile Christian in Jerusalem by Jews from Asia /Ephesus (Ac 21:29). The presence of these delegates and (at least some of them) recognisable co-workers of Paul would surely be noticed. It might even have been a problem to host the Gentile Christian delegation in Jerusalem. Who would want their house ritually defiled by Gentiles and that under the eyes of critical neighbours? Perhaps this is why Mnason is explicitly mentioned as the host of the group (Ac 21:16). Schnabel (2012:859) notes that he possibly was among the early Hellenistic Jewish believers from Cyprus who had to leave Jerusalem after the death of Stephen and who brought the gospel in Antioch (11:20). With this background, Mnason would be ready to host Gentiles Christians.

11.See the fierce resistance which Paul faced according to Acts 21-25. Here one needs to distinguish between the general stance towards Gentiles (there was no consensus embraced by al Judean Jews) and reactions against fellow Jews who were seen as introducing elements alien to Judaism or as compromising Jewish identity in the upsurge of the efforts to safeguard Jewish identity. While some tensions existed there was no overt hostility towards Gentiles before the outbreak of the first Jewish war.

12.On Herod Agrippa I, see Schwartz (1990). Possibly ever since their ministry to the Hellenist widows, the appointment of Hellenistic men to serve them and to play other prominent roles in the community and the ministry and persecution of the Hellenist Stephen and other Jewish Christians with this background, the Christians of Jerusalem would have been suspect in the eyes of some Jews because of their ready association with Hellenistic Jews. 
however, he took the part of the Jews in the East against the Greeks. After the year 54, the world had an aggressively Hellenistic ruler in Nero. ${ }^{13}$ The Jewish nationalists gradually developed a burning hatred of foreign domination. Aristocratic patriots on the one hand and demagogic Zealots on the other set the mood and gradually succeeded in inciting the population to rebel. Thus, the period from $44 \mathrm{AD}$ to $66 \mathrm{AD}$ inevitably prepared for the first war between the Jews and the Romans, $66 \mathrm{AD}-70 \mathrm{AD}$ ... At stake were the freedom and purity of Judaism, for which the Temple and the law were two sacred palladia. Zealotism led to all kinds of complications, not only for the Greek residents and the Roman authorities but also for the Christian congregations. For the church, the period of the second procuratorship bore a double stamp: on the one hand, the loyalty to Israel of James; and on the other hand, the Gentile mission of Paul. Theological and personal differences hardly suffice to explain this polarity; we must rather examine the historical circumstances under which the Jewish Christians and Gentile Christians lived. (Reicke 1968:203; author's own italics)

Reicke describes the development of this Jewish struggle against Hellenistic and Roman culture and power. In this prolonged struggle, each Jewish success encouraged the patriots and zealots to further action (Reicke 1968:205f.). Therefore, already in the year $54 \mathrm{AD}-2$ years before the visit of Paul and his delegation to Jerusalem to deliver the collection - 'hosts of Zealots stood ready to intervene against foreigners and enemies' (Reicke 1968:206). ${ }^{14}$ In this tense political context, the Jewish Christians in Jerusalem faced different challenges: on the one hand, loyalty to their fellow Jews in difficult times (threats to Jewish identity), conscious of their role as God's chosen people, and on the other hand concern for the Gentiles, who were in need of salvation and to whom the church had been commissioned to reach out and had done so with some success. According to many scholars, including Reicke (1968), these different:

interests were represented characteristically, though not exclusively, by two Apostles, the one a leader in Jerusalem, the other in the mission field. These were James, the brother of the Lord, and Paul, the Apostle to the Gentiles. Their life and work reflect the political and ethnic problems of the period. (p. 211) $)^{15}$

In this understanding, Paul's full acceptance of Gentile Christians into the people of God represented a disputed position that had far-reaching implications and repercussions for the church in Jerusalem. ${ }^{16}$

13. Reicke (1968:206) notes that when the hellenophile Nero had scarcely been proclaimed emperor in $54 \mathrm{AD}$, zealots rose up against Greeks and even Romans in udea. This was the beginning of an organised campaign of resistance which 12 years later culminated in open war. The despotism of Nero, which did not become apparent until the sixties, but was caused by his open and staunch support of Hellenism. 'On the basis of personal reminiscences, Josephus describes how the Holy Land became filled with anarchists ("robbers") and fanatics ("conjurers") just after Nero's accession' (Josephus, Ant 20.158, 160).

14.Traces of this can also be seen in the Christian community in Jerusalem. During the first missionary journey, Gentiles were received into the church without prio conversion to Judaism (Ac 13f.). This development was criticised by some Christian Pharisees in Judea (Ac 15:1,5) at a time when many Jews were "beginning to gathe courage once more under the unstable procurator Cumanus (AD 48-52)' In this situation, the relationship between Jewish and Gentile Christians with all its implications would become a pressing issue; see Reicke 1968:213).

15.Paul's predominantly Gentile Christian communities probably also benefitted from the close association of the Jewish Christians in Jerusalem with Judaism.

16.This position is problematic as it underestimates Paul's concern for his fellow Jews and the willingness of Jewish Christians to include Gentiles.
These wider developments most likely affected the Christian community of Jerusalem, although it is difficult to reach reliable conclusions. In the words of Reicke (1968):

Since in the fifties the nationalism and Jerusalem-centred politics of these circles could easily lead to Christian involvement in the Jewish Zealot turmoil, Paul spoke not theoretically but on the basis of painful experience when he wrote ... to the Romans ...: in the first part, he warns against pride in the Jewish law (Rom 2:17-29); in the second, he urges obedience to the Roman government (Rom 13:1-7) and rejects combativeness and 'zeal' (Rom 13:13). Soon afterward, in Jerusalem, he was forced to discover that thousands of Jews who belonged to the church were also zealous for the law (Ac $21: 20) .{ }^{17}$ (p. 222)

We will come back to Paul's letter to the Romans below. In this context, Reicke also explains why Gentile money would have been welcome to the Christian community of Jerusalem earlier on when Paul and Barnabas were charged to remember the poor (Gl 2:9f.) and how this situation changed soon thereafter:

... the year of the Council, 49 , was preceded by the years $44-48$, a period of political calm but economic crisis. There was little fear of Jewish reprisals against the church on account of its Hellenistic ties; aid from abroad, however, like that now to be undertaken by Barnabas and Paul (Gal 2:10), was all the more welcome. ${ }^{18}$ After the Council, from the year 50 , the pressure of Judaism increased once more, help from abroad no longer appeared necessary. ... As a consequence, the agreement of the Apostolic Council, despite ecumenical ideals, remained a product of peculiar circumstances. (Reicke 1968:214)

The developments of the following years would have made it increasingly difficult for the Jewish Christians of Jerusalem to keep their ties with Paul - with his law-free Gentile mission and its converts: this mission and its inclusion of Gentiles into the people of God on equal terms exposed the community in Jerusalem once more and in a greater degree to the antiHellenistic elements in Jerusalem and Judea. That the impact and conditions of Paul's mission in the diaspora and their implications for Jewish identity would eventually become known in Jerusalem is suggested by Acts 21:27: Jews from Asia Minor recognise Paul in Jerusalem and can readily identify one of his travel companions, the Ephesian Trophimus, as a Gentile. They charge Paul for bringing Gentiles into areas of the temple precinct which were reserved for Jews. Reicke (1968) refers to:

the victory in the struggle against Hellenism which Agrippa II, Jonathan the high priest, and, in the background, the Zealots were able to celebrate in AD 52 thanks to Claudius' good will. In the same year, the Christians in Palestine were harassed by the Jews, a situation over which Paul lamented bitterly during his second missionary journey (1 Thess 2:14-16). And after Nero's accession in 54 and the outbreak of the fearful Zealot violence ...

17.The developments in Judea also impacted the Gentile Christian communities which Paul had founded. The widespread opposition of Judaisers to Paul must be understood against this backdrop.

18.This observation would apply all the more if the meeting described in Galatians 2:1-10 is to be equated with the earlier famine-relief visit of Acts 11:27-30, rather than with Acts 15; for a survey of the possible equations, see Wenham (1993) and Zeigan (2005). 
accommodation of the church to the tradition of legal observance and circumcision seemed the only way to preserve the Jewish Christians from destruction. (p. 214)

This brief sketch of the challenging situation in which the Christians of Jerusalem found themselves in suffices. It is difficult to discern whether and/or to what extent Paul was aware of the potential implications which his arrival and longer stay with a larger group of Gentile Christians, a larger sum of money of Gentile origin ${ }^{19}$ and the acceptance of the collection would have had for the Christians of Jerusalem within the framework of the inner Jewish disputes regarding Jewish identity and Gentiles during this period. ${ }^{20}$ Haacker (2012, adopting Paul's perspective and intention) describes the implications of the collection for the Christians of Jerusalem as follows:

The acceptance of the donations would be an act of recognition of the churches founded by Paul. ... In accepting or rejecting the Gentile Christian donations the church in Jerusalem had to take a decision and position in this current inner-Jewish debate; it could lose the sympathies which it had among the city's wider population and might even face oppressive measures from the sicarii. The fact that Paul thought that a rejection by the saints is possible suggests that he counted on a significant influence of radical forces among the Jewish Christians of the Jewish motherland. (p. 9f., author's own translation)

In addition to the challenges because of the political situation, one should also note that already in the Old Testament, not all money was acceptable for use in religious contexts. ${ }^{21}$ For example, the wages for male or female prostitution could not be used to redeem vows (Dt 23:18). Nehemiah left no doubt that Gentiles would have no share or claim or historic right in Jerusalem (2:20). It is also noteworthy that the 30 pieces of silver returned by Judas Iscariot to the temple (as an act of expiation) were not simply returned to the temple treasury because it was 'blood money' (Mt 27:5-7).

It is difficult to assess whether the obstacles to accepting the donation and its donors consisted only of already existing and anticipated further pressure from the side of non-

19. Haacker (2012:10) notes that according to Josephus (Bellum 2, 408f.) there was a heated discussion in the years before the outbreak of the war whether it was legitimate for Jews to accept donations from Gentiles. This debate concerned among other issues - the Roman subsidies for the expenses of the cult in the temple of Jerusalem. Under the leadership of the temple captain Eleazar, a refusing attitude became dominant. Josephus interprets the refusal of Gentile money as declaration of war on the Romans. The same sceptical attitude over against Gentile donations also appears in a saying, which the Tosefta ascribes to first century AD donations also appears in a saying, which the Tosefta ascribes to first century AD sage R. Jochanan ben Zakkai (TSota 14,10 [321]). Schürer et al. (1973:486) summarises Josephus as follows: '... at the instigation of Eleazar, the son of Ananias the High Priest, it was now decided to suspend the daily sacrifice for the emperor 列 acrifice for the enpolt against the Romans'.

20.According to Reicke (1968:214), 1 Thessalonians 2:14-16 suggests that Paul was aware of the developments in Judea (at least at the time of writing). Did precisely this pressure on the Christians in Judea spurn Paul on in gathering the collection so that the material needs of these Christians could be alleviated? Did Paul want to demonstrate to Jewish Christians and other Jews that Jews would benefit from Gentile inclusion? Garland (2003:756) observes that Paul's coming to Jerusalem with the delegation is similar to his earlier strategy of bringing along Titus to the first meeting in Jerusalem to sort out the Jew/Gentile issue (G| 2:1-5). The presence of Titus was intended as a provocation, 'designed to prompt a positive decision from the from the Jerusalem apostles about their acceptance of uncircumcised Gentile believers. In the same manner, the tangible evidence of the faith of the Gentiles and their gratitude represented by the collection probably was intended by Paul to 2003:756). Did go wrong the second time what worked well the first time around?

21.For different attitudes in Early Judaism, see Murphy-O'Connor (1996:342f.)
Christian Jews on the Christian community or whether more or less massive reservations also existed among some Jewish Christians against Paul and the parameters of his Gentile mission and Gentiles Christians per se. While Acts 21:15-20 claims that this was not the case for the leadership of the community, others apparently were highly sceptical of Paul (see above). Did they (still) adhere to the earlier decision of the council quoted in Acts 21:25 or had they recalled their agreement and returned to the earlier demands of circumcision? If the content of Paul's letter to the Romans can be used as a quarry for Paul's plea for the delivery of the collection in Jerusalem (see below), its extended discussion of Gentiles and Jews (including the value of circumcision) suggests that more was involved than pressure from the outside. Probably other factors were also involved.

How did Paul address these severe obstacles? Different from addressing and overcoming the obstacles in Corinth, Paul did not, as far as we know, address the recipients in Jerusalem directly before the delivery of the collection as he did through a letter regarding his impending visit to Rome. Thus, we do not have any direct information. Paul informed the Romans of why he would venture eastward once more before eventually coming to them and requested their prayers for the impending journey to Jerusalem. One may therefore safely assume that at least some of what Paul wrote to the Romans, immediately before setting out for Jerusalem and aware of the problems and challenges which his arrival there would imply, would also have been on his agenda for and during the delivery of the collection and the plea for its acceptance. Some scholars have argued that the church in Jerusalem is the second, secret or inner addressee of the letter to the Romans anyway (G. Bornkamm, J. Jervell, U. Wilckens). Says Wilckens (1987:46): 'Thus automatically and at the same time Romans takes the shape of a preparation of Paul's speech of defence in Jerusalem'. Paul wrote Romans with his impending visit to Jerusalem and all the challenges it involved, in mind (see Haacker 2012:14). ${ }^{22}$ According to Horn (1995:40), Paul presents with his letter to the Romans an apology for his theology and practice as if he was writing to Jerusalem.

Therefore, in some sense all of Romans 1:15-15:13 can be taken as a preparation, theological justification and defence of Paul's collection, mentioned in Romans 15:25-31 (see Jewett 2007:83). This case has been argued in some detail by Jervell (1991):

The essential and primary content of Romans (1:18-11:36) is a reflection upon its major content, the 'collection speech', or more precisely, the defence which Paul plans to give before the church in Jerusalem. To put it another way: Paul sets forth and explains what he, as the bearer of the collection given by the Gentiles for the mother congregation in Jerusalem, intends to say so that he as well as the gift will not be rejected. (p. 56)

While this assessment is perhaps exaggerated, Romans gives a number of clues as to Paul's argument on why the Jewish

22. For a recent assessment see Schnabel (2015:41): The relevance of the forthcomin visit to Jorusalem has inded to be reckoned with in the interpretation of the visit to Jerusalem has ineed to be reckoned with in . intended to write and send along to Jerusalem with the Corinthian delegates might have been similar to the letter to the Romans. As Paul later chose to lead the delegation to Jerusalem himself, these letters were probably never written. 
Christians of Jerusalem should accept the collection and their Gentile Christian brothers and sisters - despite all obstacles, whether Paul was aware of these or not. A brief survey has to suffice.

While Paul leaves no doubt about the state of Gentiles before coming to faith in Romans 1:18-32, he also notes in Chapter 2 that the Jews have not properly used the privileges they had. Thus, there is no cause for feelings of superiority. At the end of this chapter, Paul relativises Jewish identity and privileges considerably. All people have failed and need justification by grace. This shared need and salvation unites Jews and Gentiles (Ch. 3). Abraham is not only the patriarch and founding father of Israel but also the father of believing Gentile Christians (Ch. 4). In Chapter 5, Christ is compared to Adam, the first human being and origin of all humans. While the Law, spiritual and good in itself, was Israel's treasured possession and privilege against the 'lawless' nations, it proved insufficient against the power of sin and the human flesh (Ch. 7). The Law was not the solution for Jews neither will it be for Gentiles. The Law, the document of Israel's election and basis for her strict separation from the nations, has now come to an end in Christ (10:4). The crucial difference is made by association with the death, burial and resurrection of Jesus, expressed in baptism (Rm 6) and by living in the Spirit (8:1-18). Both options, Paul emphasises, are open to Jews and Gentiles alike.

In Romans 9-11, Paul, on the one hand, affirms the special status and privileges of Israel and reveals eschatological promises that no other people enjoy. Paul leaves no doubt as to the Jewish nature of the Gospel (see the survey in Stenschke 2012). On the other hand, Paul has relativised the status of Israel by showing that Jews need salvation as much as Gentiles do: all are under the dominion of sin (Chapters 1-3). Paul's reference to the collection is not surprising after his exposition about the lasting significance of Israel, of the Jewish Christians as the remnant of Israel which guarantees the eventual salvation of all of Israel, of the future significance of Jerusalem ('Out of Zion will come the Deliverer ...', 11:26) and in view of his repeated affirmation of his own deep bond with Israel in Romans 9-11.

In Romans 14, Paul argues for mutual tolerance in the congregations of Rome. There is to be no room for contempt and passing of judgement on each other. The 'strong', probably predominantly Gentile Christians, must limit their freedom so that the 'weak', probably mainly Jewish Christians, may hold on to what they cherish (Rm 14:2, 5, 21; see the survey in Haacker 2012:329-356; Jewett 2007:829-899; Reasoner 1999).

In view of this Pauline assessment of Jews and Gentiles and his instructions to Gentile Christians, there is no need to be worried by the influx of Gentile Christians into the people of God. Let there be no doubt that the Gentile Christians who send their gifts to Jerusalem are truly believers, indeed children of Abraham as Jews, and part of the people of God, although by faith only (Rm 4). The Christians of Jerusalem can be sure that Paul has instructed the Gentile Christians regarding their surprising status (wild shoots grafted into the rich root of the olive tree to replace the noble branches which had been broken off because of their unbelief, 11:17, 20), the inappropriateness of all boasting and feelings and display of superiority and their need to persevere in the faith - 'So do not become proud but stand in awe. For if God did not spare the natural branches, neither will he spare you' (11:20). His instruction included the immense debt which the Gentile Christians owe to Jewish Christians (15:27).

In Romans 15, Paul makes this explicit when he presents an exclusively theological rationale of the collection. For Paul, far more than mutual sharing of resources was involved (compare the diverging rationale for the collection in 2 Cor 8f.): the Gentiles have come to share in the spiritual blessings of the Jewish Christians (and Paul ensured that they knew and appreciated this), therefore they also ought to be of service to them in material things (15:27). Such service is not optional, but its necessity derives from the salvationhistorical priority of Israel and the factual course of the early Christian mission ( $R m$ 1:16: 'to the Jew first and also to the Greek'), in which the Gentiles received the Gospel through Jewish Christian missionaries venturing forth from Jerusalem and Antioch. Through their contribution (with some strong nudging on the side from Paul, passed over in silence in Romans!), the Gentile Christians acknowledge their indebtedness to Israel, to the origin of God's salvation and the gospel..$^{23}$ Now it is up to the Christians of Jerusalem to acknowledge them. They should rather accept and honour what God has done among the nations (the argument of the Book of Acts) than side with unbelieving Jews in their rejection of Gentile Christians or in politically expedient dissociation from them.

As he needed them for gathering the collection, so Paul will need all his leadership skills for the impending delivery of the collection in Jerusalem under such delicate circumstances. He could not determine but had to negotiate the terms and circumstances for the presentation of the collection in a way that would not endanger the recipients in a tense situation and persuade the recipients to receive the donation and its donors on his terms, that is the link between donation and donors and the significance which Paul ascribed to it. ${ }^{24}$

In all this Paul would be carefully observed by friends and foes alike. He had to demonstrate his integrity and guarantee full transparency in a matter that was before 'all the churches'. His own integrity and credibility was at stake. Add to all of this that Paul himself was not undisputed and had been

23.Little (2005) observes that in addition to demonstrating Gentile indebtedness, Pau specifically aimed at converting Israel to faith in Jesus as the Messiah in fulfillment of the Old Testament prophecy: 'Thus, it appears that the means to the end of fulfilling his redemptive program for Israel was by demonstrating indebtedness. What this signifies is that displaying Gentile indebtedness was necessary and What this signifies is that displaying Gentile indebtedness was necessary and subservient to accomplishing his primary goal regarding the salvation of his own nation' (Little 2005:168). Paul's collection enterprise aims at 'saving Israel by way of demonstrating the Gentiles' gratitude' (Little 2005:169). These statements need to
be pursued in view of the discussion in Romans 11.

24.According to Acts 21:20-27, Paul was sensitive to the situation on site and followed the proposal of the Jerusalem leaders. 
facing many and various opponents for years, some of them from Jerusalem. ${ }^{25}$ The delivery of the collection in Jerusalem is one of the events in the history of early Christianity (as recorded in the New Testament) which posed a major threat to these Christians and required careful consideration of the larger political context to minimise its risks (others are recorded in detail in Acts 5-8:4).

\section{Obstacles on the side of Paul himself and his response}

In his own biography, Paul had overcome the reservations that some Jewish Christians might still have harboured against Gentile Christians becoming part of the people of God as Gentiles. He had developed a new vision regarding Jewish election and identity as well as its preservation in a Gentile world (see 1 Cor 9:19-23, see Rudolph 2011). Paul had invested much time and effort in the collection. A number of his co-workers were involved whom Paul could not employ elsewhere (2 Cor 8f.; Ac 20:4). He was willing to venture eastward once more although he actually considered his ministry there completed and his eyes were firmly set on new tasks in the West, as he explains in Romans 15:18-32.

In addition to the procrastination of his own plans regarding first Rome and then Spain and the general strains and dangers of travelling in antiquity for Paul and the delegation (see Casson 1976:128-265; Deissmann 1911:43-46; Heinz 2003), Paul was fully aware of the dangers involved for him when travelling to Jerusalem ${ }^{26}$ and in Judea itself: he asked the Romans to join him in earnest prayer that he may be rescued from the unbelievers in Judea (15:31; for Paul's theology of persecution, see Penner 2011:257-339). Shortly before departing to Jerusalem, Paul was aware that the collection might not even be accepted by the recipients (see above).

Another challenge for Paul and his companions was the mere logistics of the collection. This entailed bringing the delegates together at one specific time and place and then to lead this larger group on to Jerusalem and guarantee the safe transport and delivery of the funds. Garland (2003) describes some of the challenges involved:

If a large amount were collected, a larger number of couriers would be required to transport it. The security of the funds would have been a major issue, and Paul assumes that there is safety in numbers. He could not hire an armoured chariot to transfer the funds! Murphy-O'Connor (1996:345-346) notes that the money would have to be converted to the smallest volume to transport it. Pack animals would have invited the unwanted attention of bandits who controlled the countryside in

25.Acts 21 reports a warm welcome of the delegation in Jerusalem (v. 17). The whole group went to see James and all the elders. Paul reported in detail the things that God had done among the Gentiles through his ministry (divine approval of the Gentile mission as an argument for its legitimacy also appears earlier in Acts). This friendly statement of account was met by approval and led to praise of God. Nothing is said regarding the acceptance or rejection of the collection. Then Pau was requested to demonstrate and prove his own loyalty to the law to the 'many was requested to demonstrate and prove his own loyalty to the law to the many thousands of believers who are among the Jews, and they all are zealous of the law' (v. 20). Apparently they believed the slander of Paul's opponents and now had to be convinced of the contrary. Luke does not

26.See his safety measures according to Acts 20:13; for an alternative reading, see Schnabel (2012:837) many areas. More inconspicuous means would have been chosen to convey the money. Murphy-O'Connor imagines that the couriers would carry the funds in a money belt or in a bag suspended from the neck and also would have sewed gold coins into their garments in such a way that they would not clink or misshape the clothing. (p. 756f.)

Paul's response to these obstacles was straightforward. Despite his own dark foreboding of what might happen (Ac 20:22-24; Rm 15:31) and serious warnings along the way (Ac 21:4 'Through the Spirit they told Paul not to go on to Jerusalem', vs. 10-14 'Thus says the Holy Spirit: "This is the way the Jews in Jerusalem will bind the man who owns this belt and will hand him over to the Gentiles"'), Paul was willing to take these risks. Acts reports these warnings without passing judgement on Paul's insistence to travel onward to Jerusalem. ${ }^{27}$ Was Paul right in continuing his journey despite this? Was it a case of admirable commitment to Christ or of human stubbornness or a mixture of both? Murphy-O'Connor (1996) describes the alternatives which were available to Paul:

Paul could have decided not to return to Jerusalem. His participation in the delegation was not imperative. The delegates of the contributing churches were with him, and he could have given back the money and opted out. Or they could have gone ahead without him. The only injury would have been to his pride. His decision to persevere, despite mortal danger and the possible futility of the gesture, underlines how deeply he felt about the relationship between the Jewish and Gentile churches. No one was more conscious of the profundity of the widening gap between those for whom Christ was central and those for whom He was not. Yet it was desperately important to fling across the abyss a fragile bridge of charity. He would risk all in the attempt. (p. 343)

The size of the delegation in Acts 20:4 suggests that Paul was successful in raising a substantial sum of money. ${ }^{28}$ MurphyO'Connor (1996:345) writes that it will never be known exactly how much money Paul collected. According to him, it must have amounted to a considerable sum as the symbolic value of the gesture would have been negated if the sum were derisory (1 Cor 16:2). In that case, it would have been seen by the recipients as an expression of contempt. Unless an impressive amount had been collected, Paul probably would have considered the collection a failure. In that case, he would probably have returned the contributions to the communities, perhaps accompanied by a bitter comment on their lack of generosity.

However, we must also note that one factor should have worked in Paul's favour and probably encouraged him to proceed. He had been to Jerusalem several times before and each time was well received and successful in what brought him to the city. Together with Barnabas he had been there to deliver the famine relief collection of the Antiochene church

27.This is a clear example of the parallelisation between Paul and Jesus in Luke-Acts; for a survey, see Radl (1975).

28.Although it is possible that for Paul the representation of different geographical areas by a group of delegates was more important than the mere manpower of many carriers. 
which included Gentile Christians (Ac 11:27-30). So there was a clear precedent to draw on. During this visit, the Gentile Christian Titus had probably been with Paul and was accepted as a Gentile Christian and issues regarding the nature of Paul's gospel and his Gentile mission had been settled in Paul's favour. The Apostles had charged him to remember the poor. While not explicitly charged to remember the poor of Jerusalem, they certainly would have been included (G1 2:1-10, based on the equation between Ac 11:2730 and Gl 2:1-10; for a discussion, see Wenham 1993; Zeigan 2005). Paul could refer to this earlier agreement: after all, he only did what he was charged to do. When disputes arose in Antioch, Paul went to Jerusalem to settle them there. He accepted the decision taken there and communicated it to the churches he had founded (Ac 15-16:5). He also returned to Jerusalem after his second missionary journey (Ac 18:22), although no details are known of this visit (however, this is disputed; see Murphy-O'Connor 1996:22, 53, 94, 131).

Paul's and the Romans' prayers were not answered and the warnings became the sad truth. In Jerusalem, Paul lost his freedom in his effort of reconciling Jewish and Gentile Christians. In order to demonstrate his own Jewish identity and his appreciation of it and to overcome the suspicion which Law-zealous Jewish Christians in Jerusalem (who readily believed Jewish slander against Paul) held against Paul, he went to the temple to purify himself and to make a sacrifice. There he was arrested and almost lynched (Ac 21:17-30). The remainder of Acts is the account of Paul, the prisoner (for a survey, see Rapske 1994:115-436).

Surprisingly, in his later so-called prison letters, Paul never mentions the collection. Neither does he express his regret for going to Jerusalem and for trying to reconcile Gentile and Jewish Christians with each other. For him, the personal consequences of the collection must have been part of the suffering which was part and parcel of his apostolic calling (e.g. Ac 9:16; for a survey, see Hafemann 1993), of the good fight which he fought, of finishing the race and of keeping the faith (2 Tm 4:7).

While Paul expected other Christians to contribute and receive the collection under difficult circumstances, he himself was willing to risk his life in order to bring about reconciliation and to follow the charge to remember the poor, given to him early on in Jerusalem (Gl 2:10). While he first considered to send the sum of money through delegates only (1 Cor 16:3), he eventually led the delegation himself under these increasingly difficult circumstances. The congregations and individuals whom he had involved earlier on in this project could count on Paul to carry it through to the end with determination and utmost transparency. Paul took the strains and dangers of a further journey eastward on himself, was willing to postpone and risk his own plans for the immediate future and move into a potentially dangerous situation which could require divine deliverance from unbelieving Jews in Judea (Rm 15:31). What Paul demanded from the Christians of Jerusalem, that is, to face resistance and perhaps even persecution for their association with Gentile Christians, he was also willing to face and bear himself.

It was this integrity and readiness for personal sacrifice that others would have sensed and that would have nudged them to join in. How could others refuse to participate in view of the sacrifice that Paul himself was ready to make? This is an 'argument by sacrifice', a well-known rhetorical device which also appears elsewhere in Paul's letters. ${ }^{29}$

In this project, Paul needed all his leadership skills and wisdom for organising and carrying through the impending journey to Jerusalem with the Gentile Christian delegates: skills in heading a delegation of diverse people safely to its destination, skills in transporting and protecting a large sum of money, skills in appreciating what approach and solution was possible under the given circumstances, skills in preparing and negotiating the actual handing-over of the collection, skills in arguing for its acceptance, skills in keeping a low profile in a hostile context and skills in demonstrating his Jewish identity and solidarity with the Jewish Christians of Jerusalem and with the Gentile Christians who had come with him and those who sent them.

\section{The portrait of Paul the leader in overcoming the obstacles on the side of the Jewish Christian recipients and on his own side: Summary and analysis}

Because of the lack of ancient sources, interesting questions regarding the recipients and the success of Paul's efforts remain unanswered: were the Christians of Jerusalem convinced by his arguments? Did Paul get the opportunity to present his case? Were the other delegates involved, and if so, how? Did the recipients eventually accept the collection and, with the money, wholeheartedly also its Gentile Christian donors? In the end, did Paul really do the Christians of Jerusalem a favour with the whole enterprise or did he endanger them needlessly? Was Paul right in pressing on despite all warnings? However, what has become clear in Parts I and II of this study is that the collection involved a number of obstacles for all involved and that this required skilful leadership.

Despite the scarcity of information, it is possible to summarise some traits of Paul the leader in the collection enterprise. Here we focus on the obstacles regarding the recipients and himself and Paul's response to them: ${ }^{30}$

- Because of the gravity of the matter, the amount of money collected and the size of the delegation, the uncertain

29. Hansen (1993:825) notes that in argumentation by sacrifice, 'sacrifice is presented as evidence of the value of the thing for which the sacrifice is made. Paul frequently points to the sacrifice of the cross as the basis for the value of the freedom in Christ which the false teachers were attempting to destroy'.

30.For surveys of Paul's understanding of leadership, see Clarke (2000:173-252), Walton (2000) and Barentsen (2011). 
outcome of the collection, the reservations about him held by some Christians in Jerusalem, the presence of opponents who sought to undermine his authority and trustworthiness and the fierce resistance which was to be anticipated from other Jews, Paul decided that his personal presence would be necessary. Under these circumstances and in contrast to his practice elsewhere and at other times, he trusted his own skills and spoken words more than written letters or the members of the delegation. Paul was willing to take action himself rather than leaving a sensitive and difficult task to others. He was willing to bear the strain and dangers of travelling eastward once more and accepted the delay of his own plans for the future which this implied. We do not know to what extent he counted on his travel companions, some of them Gentile Christians, to support him. It is not clear what role they were to play and actually played. Possibly their perception of their role differed from what Paul had in mind.

- Despite his insistence on his authority as an apostle of Jesus Christ (in Gl 1:1; 1 Cor 1:1; 2 Cor 1:1; Rm 1:1-5 and elsewhere in the letters which mention the collection), Paul could not simply command the acceptance of the collection from the recipients. During his visit in Jerusalem, Paul had to use all his rhetorical skills to win and persuade by speech. ${ }^{31}$ Based on his letter to the Romans, written while Paul prepared for the journey to Jerusalem, Paul would draw on the undisputed authority of the Old Testament, expound his analysis of universal human failure and universal salvation through faith in Jesus Christ, refer to the example of Jesus Christ as a model to follow and argue with reference to salvation history (Jewish Christian priority and the Gentile Christian debt to Jewish Christians) and his vision of Jewish-Gentile relations as outlined in Romans 9-11. Based on his argument in 1-2 Corinthians, it is safe to assume that Paul would place his request of the Christians in Jerusalem in a wider ecumenical perspective and would remind them that their reputation and recognition in the wider Christian community were at stake, as no church is an island entirely to itself. Despite her prominence, this also applied to Jerusalem. In doing so Paul also employed a wider rhetorical strategy of establishing and defending his disputed apostolic authority. The collection is a case of leadership through persuasion based on theology and attuned to cultural conventions.

- Paul's leadership in the collection becomes persuasive through his own intensive personal involvement in gathering the sum and through the risks which he was willing to take for its delivery ('that I may be rescued from the unbelievers in Judea', Rom 15:31). While Paul had demanding expectations of the donors and recipients, he was willing to take the lead and to serve, even to the extent of risking his life. This type of leadership is not professionally detached but highly involved (see below).

31. Despite the brief reference to his signs and wonders during his ministry up to the point of writing in Romans 15:19, it is unlikely that Paul intended to perform further signs and wonders in Jerusalem (perhaps as signs of divine approval of his
foriting ministry; see, e.g., Ac 14:27; 15:3-4), although the city is mentioned as the point of ministry; see, e.g., Ac 14:27; $15: 3-4$ ), although the city is mentioned as the point of
departure of his ministry in the same verse. Does Paul imply with his statement in Romans 15:19 that he had performed miracles before in Jerusalem?
Paul knew that the journey involved severe problems for himself, which would need divine intervention (see his request of the Romans for prayer support). Whether and to what extent Paul was aware of the difficult political circumstances in Jerusalem and the existing and potential pressures which the Christians there faced is difficult to determine. It is therefore hardly possible to assess whether he could properly assess the risk which his visit and intention held for the Christians or whether he knowingly and deliberately made allowances for this risk. According to the portrayal of Acts, the Christian leaders of the city gladly welcomed him and the delegation. The issue which they raised and wanted Paul to address was something different from what he had in mind (Ac 21:18-26). We return to this question below.

What does all of this tell us about Paul the leader in terms of current leadership studies? ${ }^{32}$ One should start with the observation that in contrast to most of the Jewish and Gentile converts through his own ministry (among them the donors of the collection), the Jewish Christians of Jerusalem (the recipients of the collection) were not Paul's evident followers. Although not unknown to them, he first had to win them over to following his demanding plan. They were at best potential followers, many of whom would have been critical of him. ${ }^{33}$ In order to achieve this, Paul would have depended on his theological insights, his considerable rhetorical skill in communicating it, the visibility of his love and concern for them and the prayers of other Christians whose support he requested in this matter ( $\mathrm{Rm}$ 15:30f.). Should Paul fail to win the recipients over, he would appear as a leader without followers - in Jerusalem and in full view of the donating Gentile Christian congregations who were represented by the delegates who had come with Paul. However, we have seen in Part I of this study that Paul also had to convince the Gentile Christian donors to participate in his vision. He must have succeeded in doing so; otherwise he would not have taken the risk to travel to Jerusalem with a larger delegation as he announces in Romans and as it is reported in Acts.

In his willingness to overcome the obstacles which the collection enterprise meant for himself and to put others first, Paul appears as a servant leader. ${ }^{34}$ The concept of servant leadership goes back to the various contributions of Robert K. Greenleaf from the 1970s (e.g. Greenleaf 1977) and has been developed since then (for a survey of the development and

32. Here we draw on the excellent survey and assessment of Northouse (2016), which recently appeared in its 7th edition and has become a standard text book. For lack of space, we cannot interact in detail with major contributions as in Part I. Again, several methodological issues in applying modern leadership categories to Paul defy easy and definite identifications of one particular or several leadership style(s). In contrast to modern theorising and discussion, no empirical research and verification is possible. Concerning sources, we can only examine the direct collection passages in 1-2 Corinthians (where we have to rely on Paul's assessment of the situation, presented in a highly rhetorical context!); other passages in both letters, his letter to the Romans for arguments which Paul would likely also have used in Jerusalem and the indirect evidence of Acts, were written by an ardent admirer of Paul, not by a neutral observer.

33.On the importance of followers in any discussion of leadership, see Haslam Reicher and Platow (2011:28-37), who distinguish between a perceptional approach (28-30) and a transactional approach (30-37).

34.There are also several aspects of charismatic or transformational leadership which we discussed in Part I; for a survey, see Northouse (2016:161-193). 
current state, see Northouse 2016:225-256 and http:/ /www. greanleaf.org). Servant leadership emphasises that leaders should be attentive to the concerns of their followers and empathise with them (Northouse 2016:225f.). They nurture their followers. 'Servant leaders put followers first, empower them, and help them to develop their full personal capacities. Furthermore, servant leaders are ethical' (2016:225). They lead in ways that serve the greater good of the organisation, community and society at large. Servant leaders place the good of followers over their own self-interests and demonstrate strong moral behaviour towards followers.

Paul was ready to serve and put the concerns of others first, not only by collecting and delivering funds to alleviate the material needs of others (he saw the need and empathised with the Christians of Jerusalem) but also by trying to bring about reconciliation between Gentiles and Jews and by helping his fellow Jewish Christians to understand and follow God's intentions as he understood them. ${ }^{35}$ In this way, he tried to develop their full spiritual capacities. He would not have distinguished between personal and spiritual capacities. The greater good would have been the unity of Jewish Christians and Gentile Christians and their joint praise of God. In view of the obstacles he faced, this endeavour displays empathy and willingness to set his selfinterests aside, although Paul would also have welcomed the acceptance of the collection and, together with it, the recognition which this would have implied for him and his past and future ministry.

Assessing whether Paul conformed to the ethical ideal of servant leadership as understood today is a knotty issue (see the survey in Northouse 2016:329-362). Did Paul calculate the material need in Jerusalem and use or misuse the collected funds to force the Jewish Christians to accept Gentile Christians and acknowledge his own ministry? Did the Christians of Jerusalem really have a choice in the matter? Did Paul deliberately bring a gift with many and large strings attached to it? By insisting on the acceptance of the 'problematic' donors as well as the gift, did Paul endanger Christians who lived in tense political circumstances? Did he try to force the decision by coming in person and accompanied by Gentile Christian delegates? Should he rather have come on his own or at least with a delegation of only Jewish Christians or sent less controversial people? Did he hold the proverbial 'gun' to the recipients' heads? It is difficult to know whether Paul would have asked such questions as he seems to have been fully convinced of the need and the legitimacy of his plans. He asked the Romans to pray for the acceptance of the collection ( $\mathrm{Rm} 15: 31$ ), rather than for divine guidance in the matter or altering his plans.

Northouse describes the characteristics of servant leadership (Northouse 2016:227-229) which are relevant for appreciating

35.Although it should be noted that the Christians in Jerusalem were not Paul's followers and certainly did not see Paul as a or the legitimate leader. On the side of the donors, Paul was attentive to the concerns of the followers, as willing and generous participation in the collection enterprise entailed divine blessing for the donors and praise of God. We saw in Part I that Paul had to make considerable effort to convince the donors of the benefits involved for them.
Paul as leader. One of these characteristics is conceptualisation, which is defined as 'the ability to be a visionary for an organisation, providing a clear sense of its goals and direction' (Northouse 2016:228, see also p. 233). This applies to Paul: he understood and presented himself as a visionary of a people of God consisting of Jews and Gentiles living in mutual recognition and respect for each other. $\mathrm{He}$ had and communicated a clear sense of its goals and direction. While Paul displays empathy with regard to the material needs in Jerusalem (as Northouse 2016:227 describes it: the ability of 'standing in the shoes of another person'), we do not know whether he also attempted to see or actually saw the world from the recipients' point of view. Perhaps if he was fully aware of the situation in Jerusalem and if he had stood in their shoes for more than a short moment, he would have conceptualised things differently.

This observation leads to a further characteristic, namely, awareness: 'With awareness, servant leaders are able to step aside and view themselves and their own perspectives in the greater context of the situation' (Northouse 2016:228). We do not know whether and to what extent Paul was able and ready to do so. If he had attempted to see the world from the point of view of the Jerusalem recipients and had stepped aside and viewed himself and his own perspective in the broader sense (waiting for the collection and the delegates to be ready, he certainly would have had the time to do so), would he have proceeded with the collection enterprise and insisted on its delivery in the way in which he did? Would Paul have put others (i.e. not only the material need but also the concerns of the Christians in Jerusalem) first - the sine qua non of servant leadership (Northouse 2016:234) - even if that meant calling off the collection, its delivery as planned or his personal presence? How much was at stake for him personally? Would he have made such a distinction?

In view of these critical questions, one should note that servant leadership requires people 'interested in and capable of building long-term relationships with followers' (Northouse 2016:242). Paul's restless and intensive travelling ministry, his many and long-term co-workers and mission partners, his many letters and his prayers for his congregations indicate that Paul met this standard (see 2 Cor 11:28). His long-term interest and relationship with the Corinthians, disputed though it was, enabled Paul to eventually obtain their cooperation in the collection project. To what extent Paul was able to build long-term relationships with the Christians of Jerusalem is difficult to assess in view of the limited sources. ${ }^{36}$ There is little doubt that he attempted to do so. His relationship with the Christians of Jerusalem may have gone through several phases.

In assessing the effectiveness of servant leadership, Northouse notes that not all followers want their leader to try to help, develop or guide them (Northouse 2016:233, 240).

36. We have the portrayal of this relationship in Acts and the references to Jerusalem in Paul's letters (GI 1:17; 2:1; 4:25f.; Rm 15:19, 25f., 31; 1 Cor 16:3; Zion in Rm 9:33

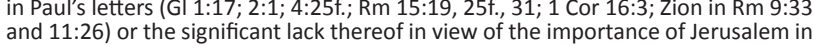
earliest Christianity. 
This reservation will have applied all the more to Paul as he was controversial in Jerusalem and many Jewish Christians, zealous for the law, were suspicious of him (according to Ac 21:20f.). They were definitely not his followers. They had to be won over to his side and Paul was willing to do so (according to Ac 21:22-27). Did Paul work on the assumption that his attempt to relieve their material need would open them for his help, development of their views and guidance?

The portrayal of Paul the leader in the context of the collection also reflects three trends which, in addition to servant leadership, have emerged in the debate about leadership in the early 21st century, namely, authentic leadership, spiritual leadership and adaptive leadership (for a brief survey, see Northouse 2016:4f., for detailed descriptions of authentic leadership and adaptive leadership, see pp. 195-223, 257294).$^{37}$ Here we focus on authentic and adaptive leadership.

The current discussion of authentic leadership throws an instructive light on the nature and role of Paul as leader, particularly in winning over the Jewish Christian recipients in Jerusalem (for a survey, see Northouse 2016:195-223). Authentic leadership describes 'leadership that is transparent, morally grounded, and responsive to people's needs and values' (Northouse 2016:220). This approach has an intrapersonal perspective (incorporating the leader's selfknowledge, self-regulation and self-concept, authentic leaders exhibit genuine leadership, lead from conviction and are originals, not copies), an interpersonal perspective (it is relational, created by leaders and followers together; 'authenticity emerges from the interactions between leaders and followers. It is a reciprocal process because leaders affect followers and followers affect leaders', Northouse 2016:196) and a developmental perspective (emphasising that it can be nurtured in a leader and develops over a lifetime). In a developmental perspective, authentic leadership has been described as a 'pattern of leader behaviour that develops from and is grounded in the leader's positive psychological qualities and strong ethics' (Northouse 2016:196). There are four distinct but related components to authentic leadership: self-awareness, internalised moral perspective, balanced processing and relational transparency (Northouse 2016:196, detailed description on p. 203).

Both parts of our study indicate that Paul emphasised transparency (he leaves no doubt about his intentions and concrete actions; however, there is more to relational transparency): his plans were deeply grounded in his morals (his own calling, the Scriptures of Israel and compliance with God's activity); he tried to respond to people's needs and

37. Northouse does not discuss spiritual leadership. According to the International Institute for Spiritual Leadership, 'Spiritual leadership involves intrinsically motivating and inspiring workers through hope/faith in a vision of service to key stakeholders and a corporate culture based on the values of altruistic love to produce a highly motivated, committed and productive workforce. The purpose of spiritual leadership is to tap into the fundamental needs of both parpors and spiritual leadership is to tap into the fundamental needs of both leaders and followers for spiritual well-being through calling (life has meaning and makes a difference) and membership (belonging); to create vision and value congruence across the individual, empowered team, and organization levels; and, ultimately, to foster higher levels of employee well-being, organizational commitment, financia performance, and social responsibility' (see lispiritualleadership n.d.). Severa aspects of this approach can be seen in Paul's leadership with regard to the collection. aimed at persuading them on the basis of their values. If our above understanding of Romans is correct, then the imminent leadership challenge of convincing the Christians of Jerusalem to follow him also had an impact on Paul and his presentation of the Gospel in Romans. His followers-to-be also affected Paul. The leadership which Paul provided in the whole collection enterprise was based on experiences and insights which had developed over a long period of time and through much hardship (the 'major life events' Northouse refers to, 2016:196, 205; 'Critical life events act as catalysts for change'; see Paul's calling and/or conversion and his suffering). We have seen that it is difficult to assess the nature of the 'strong ethics' involved in the enterprise.

Northouse also notes that authentic leaders have the capacity to open themselves up and establish a connection with others (Northouse 2016:199). Paul's arguments vis-à-vis the donors and his success in gathering the collection indicate that he was able to establish a connection with others; his behaviour in Jerusalem indicates that he tried to do the same in Jerusalem (Ac 21:20-26, he followed the advice he was given). ${ }^{38}$ Paul's letters indicate his ability for 'high-quality communication in which leaders and followers demonstrate a high degree of mutual trust, respect, and obligation toward each other' (Northouse 2016:199). ${ }^{39}$ The 'internalised moral perspective', mentioned above as one of the components of authentic leadership, refers to how leaders use their internal moral standards and values to guide their behaviour rather than allow outside pressures to control them. Paul claims a large measure of these internal moral standards and values: no outside pressures can prevent him or control him even when this implies serious consequences. In hindsight, one may ask whether the outside pressures (the situation in Jerusalem, the hostility of non-Christian Jews) should have controlled Paul and led him to a change of plan.

The five basic characteristics of authentic leaders described by George (2003; quoted by Northouse 2016) can be applied to Paul:

1. They understand their purpose,

2. they have strong values about the right thing to do,

3. they establish trusting relationships with others,

4. they demonstrate self-discipline and act on their values, and

5. they are passionate about their mission (i.e. act from their heart). (p. 197)

Paul certainly understood his purpose in God's plan $^{40}$ and, despite all obstacles, he was convinced that the collection was appropriate and he carried it through to the end.

38.In his letter to the Romans, Paul considerably opened himself up and made every effort to establish a connection with the recipients.

39.1-2 Corinthians and the brief note in Romans 15:31 indicate that at least not all the donors and the recipients had a "high degree of mutual trust, respect, and obligation' towards Paul. Therefore, the collection enterprise involved considerable effort.

40.Northouse's (2016:197) description of the real sense of purpose which authentic leaders display directly applies to Paul: 'They know what they are about and where they are going. In addition to knowing their purpose, authentic leaders are inspired and intrinsically motivated about their goals. They are passionate individuals who have a deep-seated interest in what they are doing and truly care about their work'. 
He demonstrated self-discipline ${ }^{41}$ in overcoming the obstacles he faced and was passionate about this mission. Measured by these standards, his leadership was genuine and real. Rather than merely writing to the Christians of Jerusalem as originally intended (1 Cor 16:3), he travelled there himself with the purpose of convincing them and establishing a trusting relationship with them. Would they be willing to trust his leadership? This leads us to a further observation.

Current leadership theory also offers interesting perspectives on Paul the leader with regard to the particular role which he intended to play for the recipients in Jerusalem. The concept of adaptive leadership goes back to the seminal studies of Ronald A. Heifetz and his colleagues since the 1990s and concerns 'how leaders encourage people to adapt - to face and deal with problems, challenges and changes' (Northouse 2016:257). It focuses on the adaptations required of people in response to changing environments. Adaptive leaders prepare and encourage people to deal with change. They summon:

others to face difficult challenges, providing them with the space or opportunity they need to learn new ways of dealing with inevitable changes in assumptions, perceptions, beliefs, attitudes, and behaviours that they are likely to encounter in addressing real problems. (Northouse 2016:258)

It is a leadership approach which focuses on helping others to explore and change their values (for a detailed description, see Northouse 2016:257-294).

If Paul can be understood as a leader-in-waiting for the Christians in Jerusalem, then some aspects of this leadership type may be discernible. Through his visit and the larger Gentile Christian delegation (some of them proven coworkers, representatives of churches/regions and leaders themselves) who accompanied him and a longer stay, Paul sought to help the recipients to adapt to challenges and changes. The challenges of accepting the collection and its donors and the change which this acceptance might have implied for the community, its self-understanding and safety in a hostile environment, have been described above. These challenges concerned core feelings and convictions: the recipients were called to associate with Gentiles not only in remote places but also in Jerusalem itself and under the watchful eyes of their opponents. In this context, Paul's visit and ministry to them and the presence of exemplary Gentile Christians and their interaction with them had the potential to provide the space, opportunity and orientation ${ }^{42}$ that they needed to learn new ways of dealing with changes in Jewish assumptions, perceptions, beliefs, attitudes and behaviour. These changes had become inevitable as the Lord himself had commissioned the Jewish disciples to move beyond the confines of Judaism and had affirmed such moves on many

41.Self-discipline is the trait which allows authentic leaders to remain consistent. in this way, they are predictable in their behaviour, 'other people know what to expect and find it easier to communicate [and one may add "and follow"] with them' (Northouse 2016:200).

42.Northouse (2016:267) observes that adaptive leaders help people to feel a sense of clarity, order and certainty. This reduces the stress which people feel in uncertain situations. Orientation 'is the process of helping people to find their identity within a changing system' (p. 268). occasions, including during the ministry of Paul. While there is no doubt that Paul (and probably also his travel companions) was willing to help in this process, it is difficult to determine whether and to what extent Paul would have been able to assist the Christians of Jerusalem in responding to the challenge which he presented them with and the changing political circumstances. On the one hand, he had experienced his own fair share of facing resistance from Jews and Gentiles and developed his own understanding of suffering for Christ's sake; on the other hand, he had been away from Jerusalem and Judea for long periods of time and may not have been fully aware of the current situation. ${ }^{43}$ Applying this notion of leadership to Paul underscores that leadership certainly 'is not a trait or characteristic of the leader, but rather a complex interactional event that occurs between leaders and followers in different situations' (Northouse 2016:275). For the Christians of Jerusalem to follow Paul would have been a great achievement.

Our probing into leadership theory indicates that the portrait of Paul as leader in the collection enterprise provides an instructive historical case study. To some extent, our analysis can contribute to theorising about leadership styles, although much leadership theorising is not based on historical precedent. At the same time, modern leadership theory offers fresh perspectives on the study of Paul both as a revered and also a disputed leader in the various challenges which he faced. For this quest to be productive, the focus would need to be broader than the collection enterprise.

Our brief interaction with leadership theory has also revealed several problematic aspects of Paul's leadership in the collection enterprise which one might not have been able to identify as clearly otherwise. ${ }^{44}$ Thus, it would be promising in further studies not only to compare the extant ancient evidence with modern theory as we have done, but also to set out with leadership theorising and read the ancient sources in view of it. ${ }^{45}$ Such study might demonstrate further problematic aspects or even show that Paul was less of a leader or no leader at all in modern definitions in the collection enterprise as we suggest here.

There are lessons to be learnt from Paul's leadership in the context of the collection for today's leaders. They are to lead through persuasion, are concerned about transparency, carefully and realistically think their plans and strategies through, involve other people and are willing to bear their share of the burden, which they impose on others. How this is to be done will depend on the project, the obstacles that

43.It is interesting to ask to what extent Paul himself was able to adapt - to face and deal with problems, challenges and changes' (Northouse 2016:257), when the nature of his commitment for Jerusalem changed from being asked explicitly to remember the poor (in Jerusalem?) in Galatians 2:10 (Paul affirms his eagerness to do so) to uncertainty regarding whether his service for Jerusalem would even be accepted (Rm 15:31). Who or what would help him in this process?

44.The external parameters of leadership theorising help in a critical analysis of biased sources. We only have Paul's own statements in Galatians 2:10; 1 Corinthians 16:14; 2 Corinthians $8 \mathrm{f}$. and Romans 15:25-31 (although Paul readily mentions existing or anticipated problems in collecting and delivering the collection) and some or anticipated problems in collecting and
indirect pointers to the collection in Acts.

45.In addition to Northouse (2016), Haslam et al. (2011) would be a stimulating point of departure. 
have to be overcome and the particular larger context in which the task is to be addressed and seen through to its completion. That such leadership might be challenged (at least by some) and will require determination and patience is also clear. A combination of personal calling, commitment to Christ and a clear vision of their purpose will sustain Christian leaders in the face of obstacles, risks and hardships.

\section{Conclusion}

This research combines historical and literary inquiry into early Christianity (mainly Paul's Letter to the Romans) with current leadership theory. It indicates that Paul's collection enterprise involved complex leadership challenges on the part of the Gentile Christian donors, the Jewish Christian recipients in Jerusalem and on Paul's part. Paul overcame them through high personal commitment in preparing and implementing the collection and a combination of leadership skills which can be classified as charismatic leadership, servant leadership, authentic leadership and adaptive leadership. The current leadership discussion can be applied to early Christianity and sheds fresh light on Paul. Further research could relate this portrait of Paul as leader to other aspects of his ministry in his letters and according to the book of Acts. The article reminds leaders in Christian contexts and elsewhere that complex situations require personal commitment and a combination of leadership styles. The article also indicates to what extent early Christianity was affected by and had to interact with the political situation of its day (the role of the Jewish Christian community in Jerusalem and its relation to the sentiments in Jerusalem in the run-up to the first Jewish war). It shows the complexities of Paul's late ministry and his relations to the church in Jerusalem.

\section{Acknowledgements Competing interests}

The author declares that he has no financial or personal relationships that may have inappropriately influenced him in writing this article.

\section{References}

Barentsen, J., 2011, Emerging leadership in the Pauline mission: A social identity perspective on local leadership development in Corinth and Ephesus, Princeton Theological Monograph Series 168, Pickwick, Eugene, OR.

Burns, J.E., 2010, 'Conversion and Proselytism', in J.C. Collins \& D.C. Harlow (eds.), The Eerdmans Dictionary of Early Judaism, pp. 484-486, Eerdmans, Grand Rapids, MI.

Casson, L., 1976, Reisen in der Alten Welt, Prestel, München.

Clarke, A.D., 2000, Serve the community of the Church: Christians as leaders and ministers, First-Century Christians in the Greco-Roman World, Eerdmans, Grand Rapids, MI.

Deissmann, A., 1911, Paulus: Eine kultur- und religionsgeschichtliche Skizze, Mohr Siebeck, Tübingen.

Donaldson, T., 2007, Judaism and the Gentiles: Jewish patterns of universalism (to 135 $\mathrm{CE})$, Baylor University Press, Waco.

English Standard Version (ESV), 2001, Holy Bible: English Standard Version, Crossway, Wheaton, IL.

Garland, D., 2003, 1 Corinthians, Baker Exegetical Commentary on the New Testament, Baker, Grand Rapids, MI.

George, B., 2003, Authentic leadership: Rediscovering the secrets to creating lasting value, Jossey-Bass, San Francisco, CA.
Gilbert, G., 2010, 'Gentiles, Jewish attitudes toward', in J.C. Collins \& D.C. Harlow (eds.), The Eerdmans Dictionary of Early Judaism, pp. 670-673, Eerdmans, Grand Rapids, MI.

Goodblatt, D., 2006, Elements of Jewish nationalism, Cambridge University Press, Cambridge, UK.

Goodman, M., 1987, The ruling class of Judea: The origins of the Jewish revolt AD 66-70, Cambridge University Press, Cambridge.

Greenleaf, R.K., 1977, Servant leadership: A journey into the nature of legitimate power and greatness, Paulist Press, New York.

Haacker, K., 2012, Der Brief des Paulus and die Römer, 4th edn., Theologischer Handkommentar zum Neuen Testament 6, Evangelische Verlagsanstalt, Leipzig.

Hafemann, S.J., 1993, 'Suffering', in G.F. Hawthorne, R.P. Martin \& D.C. Reid (eds.), Dictionary of Paul and his Letters, pp. 918-921, InterVarsity Press, Downers Grove, IL.

Hansen, G.W., 1993, 'Rhetorical Criticism', in G.F. Hawthorne, R.P. Martin \& D.C. Reid (eds.), Dictionary of Paul and his Letters, pp. 822-826, InterVarsity Press, Downers Grove, IL.

Haslam, S.A., Reicher, S.D. \& Platow, M.J., 2011, The new psychology of leadership: Identity, influence and power, Psychology Press, Hove.

Heinz, W., 2003, Reisewege der Antike: Unterwegs im Römischen Reich, Theiss, Stuttgart.

Horn, F.W., 1995, 'Paulusforschung', in F.W. Horn (ed.), Bilanz und Perspektive gegenwärtiger Auslegung des Neuen Testaments. Symposium zum 65. Geburtstag von Georg Strecker, pp. 30-59, Beihefte zur Zeitschrift für die Neutestamentliche Wissenschaft 75, de Gruyter, Berlin.

lispiritualleadership, n.d., What Is Spiritual Leadership?, viewed 05 August 2017, from http://iispiritualleadership.com/spiritual-leadership

Jervell, J., 1991, 'The Letter to Jerusalem', in K.P. Donfried (ed.), The Romans Debate, pp. 61-74, rev. and expanded. ed. Baker, Grand Rapids, MI.

Jewett, R., 2007, Romans: A commentary, Hermeneia, Fortress, Minneapolis, MN.

Levine, L.E., 2010, 'Temple, Jerusalem', in J.C. Collins \& D.C. Harlow (eds.), The Eerdmans Dictionary of Early Judaism, pp. 1281-1291, Eerdmans, Grand Rapids, MI

Little, C.R., 2005, Mission in the way of Paul: Biblical mission for the Church in the twenty-first century, Studies in Biblical Literature 80, Peter Lang, New York.

McLaren, J.S., 2010, 'Resistance movements', in J.C. Collins \& D.C. Harlow (eds.), The Eerdmans Dictionary of Early Judaism, pp. 1135-1140, Eerdmans, Grand Rapids, MI.

Murphy-O'Connor, J, 1996, Paul: A critical life, Clarendon, Oxford.

Northouse, P.G., 2016, Leadership: Theory and practice, 7th edn., Sage, Los Angeles, CA.

Palmer, C., 2015. 'Gentiles II. Judaism', in D.C. Allison, C. Helmer et al. (eds.), Encyclopedia of the Bible and its Reception 10, cols. 31-33, de Gruyter, Berlin.

Penner, G.M., 2011, Im Schatten des Kreuzes: Verfolgung und Christusnachfolge - eine biblische Theologie, SCM R, Brockhaus, Witten.

Price, J., 1992, Jerusalem under siege: The collapse of the Jewish state 66-70 C.E., Brill's Series in Jewish Studies, Brill.

Radl, W., 1975, Paulus und Jesus im lukanischen Doppelwerk: Untersuchungen zu Parallelmotiven im Lukasevangelium und in der Apostelgeschichte, Europäische Hochschulschriften XXIII.49. Lang, Bern.

Rapske, B., 1994, Paul in Roman custody, The Book of Acts in Its First Century Setting 3, Eerdmans, Grand Rapids, MI.

Reasoner, M., 1999, The strong and the weak: Romans 14:1-15:13 in context, Society for New Testament studies monograph series 103, Cambridge University Press, Cambridge, UK

Reicke, B., 1968, The New Testament era: The world of the Bible from 500 B.C. to A.D. 100, Fortress Press, Philadelphia, PA.

Rudolph, D.J., 2011, A Jew to the Jews: Jewish Contours of Pauline Flexibility in 1 Corinthians 9:19-23, Wissenschaftliche Untersuchungen zum Neuen Testament II.304, Mohr Siebeck, Tübingen.

Skarsaune, O. \& Hvalvik, R., 2007, Jewish believers in Jesus: The early centuries, Hendrickson, Peabody, MA.

Schnabel, E.J., 2012, Acts, Exegetical Commentary on the New Testament, Zondervan, Grand Rapids, MI.

Schnabel, E.J., 2015, Der Brief des Paulus an die Römer Kapitel 1-5, HistorischTheologische Auslegung Neues Testament, SCM R. Brockhaus, Witten.

Schürer, E., Vermes, G. \& Millar, F., 1973, The history of the Jewish people in the age of Jesus Christ (175 BC-AD 135), vol. I, T. \& T. Clark, Edinburgh.

Schwartz, D.R., 1990, Agrippa I: The last king of Judea, Texte und Studien zum antiken Judentum 23, Mohr Siebeck, Tübingen.

Seeman, C. \& Marshak, A.K., 2010, 'Jewish History from Alexander to Hadrian', in J.C. Collins \& D.C. Harlow (eds.), The Eerdmans Dictionary of Early Judaism, pp. 25-55, Eerdmans, Grand Rapids, MI.

Stenschke, C., 2012, 'Paul's Jewish Gospel and the claims of Rome in Paul's Epistle to the Romans', Neotestamentica 46, 338-378.

Stenschke, C., 2015, 'The leadership challenges of Paul's collection for the saints in Jerusalem: Part I: overcoming the obstacles on the side of the gentile Christian donors', Verbum et Ecclesia 36, Art. \#1406, https://doi.org/10.4102/ve. v36i1.1406 
Walton, S., 2000, Leadership and lifestyle: The portrait of Paul in the Miletus speech and 1 Thessalonians, Society for New Testament studies monograph series 106 Cambridge University Press, Cambridge, UK.

Wenham, D., 1993, 'Acts and the Pauline Corpus II. The evidence of parallels', in B.W. Winter \& A.D. Clarke (eds.), Ancient Literary Setting, pp. 215-258, The Book of
Acts in Its First Century Setting 1, Eerdmans, Grand Rapids, Ml.
Wilckens, U., 1987, Der Brief an die Römer, 2nd edn., Evagelisch-Katholischer Kommentar zum Neuen Testament 6.1, Neukirchener, Neukirchen-Vluyn.

Zeigan, H., 2005, Aposteltreffen in Jerusalem: Eine forschungsgeschichtliche Studie zu Galater 2.1-10 und den möglichen lukanischen Parallelen, Arbeiten zur Bibel und ihrer Geschichte 18, Evangelische Verlagsanstalt, Leipzig. 